\title{
- NOTICES AND ANNOUNCEMENTS -
}

\section{Nominations for the Editorship of Perception \& Psychophysics}

Nominations are solicited for the editorship of Perception \& Psychophysics. Charles W. Eriksen, who has been the editor since 1971, will be retiring in 1993. The new editor will begin an official 4-year term January 1, 1994, and will begin to receive manuscripts early in 1993. It is expected that the Publications Committee of the Psychonomic Society will make the appointment by July 1992.

Nominations must be submitted by April 15, 1992.

Nominations (including self-nominations) should be sent to:

\author{
Anne M. Treisman \\ Russell Sage Foundation \\ 112 East 64th Street \\ New York, NY 10021
}

\section{Nominations for the Editorship of Memory \& Cognition}

Nominations are solicited for the editorship of Memory \& Cognition. The term of the present editor, Margaret Jean Intons-Peterson, expires at the end of 1993. The new editor will begin an official 4-year term January 1, 1994, and will begin to receive manuscripts early in January 1993. It is expected that the Publications Committee of the Psychonomic Society will make the appointment by July 1992.

Nominations must be submitted by April 15, 1992.

Nominations (including self-nominations) should be sent to:

Alice F. Healy

Department of Psychology

University of Colorado

Campus Box 345

Boulder, CO 80309-0345 


\section{APA Applies for Travel Grant for Brussels Congress}

The American Psychological Association is applying for funding from the National Science Foundation, the National Institute of Mental Health, and other federal agencies to administer a block travel grant that would allow individual travel awards to be made to US participants in the scientific program of the 25th International Congress of Psychology to be held in Brussels, July 19-24, 1992. The travel grant program will be cosponsored by APA and the US National Committee of the International Union of Psychological Science.

Applicants for awards will be judged according to criteria established by the APA Committee on International Relations in Psychology.

Requests for application packets should be directed to the APA International Affairs Office (750 First Street, NE, Washington, DC 20002-4242). The deadline for receipt of completed application forms is April 1.

\section{Call for Assistance in The Compilation of a History of the Psychonomic Society}

The Governing Board of the Psychonomic Society is pleased to announce that Robert C. Bolles has agreed to serve as the first Historian of the Society.

All members who might have information relevant to this undertaking are invited to send it directly to Dr. Bolles. Founding members and those who attended the early meetings are especially encouraged to record their reminiscences. While Dr. Bolles hopes to collect as much information as possible relevant to the history of the Society, he will concentrate first on the early history.

Dr. Bolles's address is Department of Psychology, University of Washington, Seattle, Washington 98195 (phone: 206-543-2631). 